Volume 2 Nomor 1, Mei 2021: h. 43 - 55

P-ISSN: 2722-4465, E-ISSN: 2746-8151

Lisensi Creative Commons Atribusi-NonCommercial 4.0 Internasional

\title{
Tinjauan Hukum atas Pembagian Harta Gono Gini Pasangan Suami Istri yang Bercerai
}

\author{
Mushafi ${ }^{1}$, Faridy ${ }^{2}$ \\ 1, 2, Universitas Nurul Jadid, Probolinggo, Indonesia. \\ E-mail: cak.mushaf@unuja.ac.id
}

\begin{tabular}{|c|c|}
\hline Dikirim: 15/02/2021 & Dipublikasi: 31/05/2021 \\
\hline Info Artikel & Abstract \\
\hline \multirow[t]{2}{*}{$\begin{array}{l}\text { Keywords: } \\
\text { Law; Gonogini Treasure; } \\
\text { Marriage and Divorce. }\end{array}$} & $\begin{array}{l}\text { This article discusses the legal provisions for the distribution of gono } \\
\text { gini assets to divorced married couples. The research objective is to } \\
\text { reveal the legal aspects and juridical provisions regarding the } \\
\text { distribution of gono gini assets for divorced married couples. The } \\
\text { research method used in writing this article is normative juridical. } \\
\text { Based on the results of the research that the distribution of Gono gini } \\
\text { assets in divorce cases and divorce cases, each husband and wife gets } \\
\text { an equal half of the share. The gono gini distribution of assets refers } \\
\text { to al-Qur'an Surat an-Nisa'ayat 32, where it is stated that for all men } \\
\text { there is a part of what they earn and all women have a share of what } \\
\text { they earn as well. }\end{array}$ \\
\hline & Abstrak \\
\hline $\begin{array}{l}\text { Kata Kunci: } \\
\text { Hukum; Harta Gonogini; } \\
\text { Nikah dan Cerai. }\end{array}$ & $\begin{array}{l}\text { Artikel ini membahas tentang ketentuan hukum terhadap } \\
\text { pembagian harta gono gini pada pasangan suami istri nikah } \\
\text { yang bercerai. Tujuan penelitian untuk mengungkap aspek- } \\
\text { aspek hukum dan ketentuan-ketentuan yuridis tentang } \\
\text { pembagian harta gono gini bagi pasangan suami istri nikah } \\
\text { yang bercerai. Metode penelitian yang digunakan dalam } \\
\text { penulisan artikel ini ialah yuridis normatif. Berdasarkan hasil } \\
\text { penelitian bahwa pembagian harta gono gini pada kasus cerai } \\
\text { hidup maupun kasus cerai mati, masing-masing pasangan } \\
\text { suami istri mendapat seperdua bagian yang sama. Pembagian } \\
\text { harta gonogini mengacu pada ayat al-Qur'an Surat an- } \\
\text { Nisa'ayat } 32 \text {, dimana dikemukakan bahwa bagi semua laki-laki } \\
\text { ada bagian dari apa yang mereka usahakan dan semua wanita } \\
\text { ada bagian dari apa yang mereka usahakan pula. }\end{array}$ \\
\hline
\end{tabular}

\section{Pendahuluan}

Perkawinan menurut hukum Islam adalah pernikahan, yaitu akad yang sangat kuat atau mitssaqan ghalidzan untuk mentaati perintah Allah dan melaksanakannya merupakan ibadah (Latupono et al., 2020: 126). Perkawinan merupakan salah satu momen sakral yang umumnya akan dilalui oleh setiap manusia. Sebagai makhluk sosial manusia mempunyai naluri untuk selalu ingin hidup bersama dan saling berinteraksi dengan sesamanya dan perkawinan adalah sah, apabila dilakukan menurut hukum masing-masing agamanya dan kepercayaannya (Labetubun \& Fataruba, 2020: 57). 
Setiap perkawinan yang dilakukan ada yang berakhir sampai maut memisahkan namun ada juga yang hanya sesaat kemudian bercerai (Latupono, 2020: 242). Putusnya perkawinan yang disebabkan karena perceraian dapat terjadi karena talak atau berdasarkan gugatan perceraian. Perceraian hanya dilakukan di depan siding Pengadilan Agama (PA), setelah PA tersebut berusaha dan tidak berhasil mendamaikan kedua belah pihak (Latupono et al., 2020: 155).

Fenomena kehidupan rumah tangga yang terjadi salah paham, perselisihan, pertengkaran, yang berkepanjangan sehingga memicu perceraian yang mengakibatkan putusnya hubungan antara suami istri (Latupono, 2020a: 60). Penceraian sering kali timbul suatu friksi atau implikasi yang cukup rumit untuk diselesaikan, yaitu pembagian harta gono gini di saat ikatan pernikahan diantara laki-laki dan perempuan. Pengertian harta gono gini dalam pandangan ahli hukum mempunyai kesamaan satu dengan lainya. Menurut Sayuti Thalib, harta gono gini adalah harta perolehan selama ikatan perkawinan yang didapat atas usaha masing-masing secara sendiri-sendiri atau di dapat secara usaha bersama antara suami dan istri, (Thalib, 2004: 86). Harta bersama yang diperoleh selama perkawinan dapat berupah benda berwujud dan tidak berwujud. Harta bersama yang berwujud dapat meliputi benda tidak bergerak, benda beregerak dan surat-surat berharga. Harta bersama tidak berwujud dapat berupa hak maupun kewajiban (Latupono et al., 2020: 148).

Undang-Undang Nomor 1 Tahun 1974, harta gono gini dibagi ke dalam tiga kategori yang pertama, Harta yang diperoleh selama perkawinan. Harta ini merupakan harta yang dikuasai bersama selama perkawinan, kedua, Harta bawaan, yaitu harta yang dibawa oleh masing-masing pihak sebelum proses perkawinan dilakukan. Harta ini dikuasai masingmasing pihak sepanjang para pihak tidak menentukan lain, dan ketiga, Harta perolehan, yaitu harta yang diperoleh dari hadiah atau warisan. Harta ini dikuasai oleh masing-masing sepanjang para pihak tidak menentukan lain, (Anshary, 2016: 35).

Perkawinan putus karena perceraian harta bersama diatur menurut hukumnya masing-masing. Jika dicermati Kompilasi Hukum Islam (KHI) Pasal 85 dan 97 tentang Harta Bersama tidak memberikan keseragaman Hukum Islam dalam penyelesaian Harta bersama apabila terjadi perceraian. lalu, UU Perkawinan No 1 Tahun 1974 Pasal 37, Jika dicermati juga maka Pasal 37 Undang-Undang Perkawinan dan penjelasannya, tidak memberikan keseragaman hukum positif tentang bagaimana penyelesaian harta bersama apabila terjadi perceraian, hal ini tentu menjadi problem sosial hukum, jika penyelsaian dan penetapan Harta bersama tersebut tidak efektif dan adil dalam pembagiannya. Maka, rentan konflik antara pasangan suami istri kemungkinan bisa terjadi (Alexander, 2019: 113).

Pembagian harta gono gini akan semakin rumit ketika pernikahan yang dilangsungkan tidak memiliki ikatan hukum kenegaraan atau pernikahan yang dilakukan secara siri. Sebagaimana yang dijelaskan di atas, pernikahan yang dilakukan secara siri walaupun sah menurut hukum agama, tetapi tidak memiliki kekuatan hukum. Akibatnya, segala persoalan yang ditimbulkan menjadi hal pelik dan akibatnya selalu merugikan terhadap perempuan. Persoalan ini bagi penyusun menarik untuk dikaji dan dianalisa secara mendalam. Mengingat praktik pernikahan yang dilakukan secara siri masih banyak di tengah-tengah masyarakat kita.

\section{Metode Penelitian}

Paradigm penelitian ini berbasis penelitian hukum normatif. Secara teoritik penelitian hukum normatif ini sebagai sarana untuk meneliti data-data atau isu-isu hukum yang bersifat kepustakaan dan atau data sekunder. Menurut Soerjono Soekanto dan Sri Mamudji 
mendefinisikan penelitian hukum normatif, adalah penelitian hukum yang dilakukan dengan cara meneliti bahan pustaka atau data sekunder belaka, (Soekanto \& Mamudji, 2015: 13). Penelitian hukum normatif yang meneliti dan menelaah bahan pustaka, atau data sekunder, maka penelitian hukum normatif disebut juga penelitian hukum kepustakaan, penelitian hukum teoritis atau dogmatis, dengan demikian ingin digali dalam penelitian ini ialah tentang fungsi teori hukum dan bagaimana perannya dalam penyusunan rancangan peraturan perundang-undangan, darena sebagaimana maklum, bahwa teori hukum dalam diskursus ilmu hukum merupakan salah satu pijakan dalam menganalisis peristiwaperistiwa hukum.

\section{Hasil dan Pembahasan}

\subsection{Kedudukan Harta Gonogini dalam perkawinan}

Perkawinan merupakan pernikahan yang dibuktikan dengan akta nikah memberikan legimitasi seorang pria dan wanita untuk bisa hidup dan berkumpul dalam ikatan suami istri (Latupono, 2018: 154-155). Perkawinan mengakibatkan suatu ikatan hak dan kewajiban, juga menyebabkan suatu bentuk kehidupan bersama dari para pribadi yang melakukan hubungan perkawinan itu, yaitu membentuk suatu keluarga atau somah (gezin atau household). Salah satu akibat hukum dari suatu perkawinan yang sah adalah terciptanya harta benda perkawinan. Harta atau kekayaan perkawinan diperlukan guna memenuhi segala keperluan yang dibutuhkan dalam kehidupan berkeluarga. Mengenai kedudukan suami isteri dalam rumah tangga dan masyarakat ketentuannya diatur dalam Pasal 31 ayat (1) yang pada dasarnya adalah sebagai berikut: "Hak dan kedudukan isteri adalah seimbang dengan hak dan kedudukan suami dalam kehidupan rumah tangga dan pergaulan hidup bersama dalam masyarakat".

Dari rumusan tersebut di atas dapat diperoleh ketentuan bahwa kedudukannya sebagai manusia (Human Beings) maupun dalam kedudukannya dalam melaksanakan fungsi keluarga, dan memang pada dasarnya kedudukan pria dan wanita sebagai manusia adalah sama derajatnya karena sama-sama ciptaan Tuhan. Tujuan yang hendak dicapai dari ketentuan Pasal 31 ayat 1 ini ialah supaya di dalam rumah tangga tidak ada dominasi di antara keduanya baik dalam pembinaan rumah tangga itu sendiri maupun dalam pembinaan dan pembentukan keturunan sebagai pewaris generasi yang akan datang. Di samping itu dengan adanya ketentuan tersebut di atas akan memungkinkan isteri dapat menduduki jabatan-jabatan penting dalam masyarakat yang dahulunya hanya dimonopoli oleh pria saja. Demikian juga si isteri dapat mempunyai kebebasan untuk mengembangkan kecakapan dan bakatnya sebagaimana kesempatan yang dimiliki oleh suaminya. Tetapi yang perlu di ingat bagi isteri walaupun undang-undang memberikan persamaan dalam bertindak khususnya di dalam masyarakat jangan sampai melalaikan kewajiban yang pokok sebagai ibu rumah tangga. Karena dengan melalaikan kewajiban yang utama sebagai ibu, maka rumah tangga dapat berantakan dan bahkan hancur sama sekali.

Pasal 31 ayat (2) disebutkan bahwa "Masing-masing pihak berhak untuk melakukan perbuatan hukum". Ketentuan ini adalah sesuai dengan ketentuan dalam hukum adat maupun hukum Islam bahwa seorang isteri yang bersuami dapat melakukan tindakan hukum dalam masyarakat tanpa bantuan suaminya seperti sebelum dia bersuami. Jadi menurut ketentuan ini seorang isteri telah dapat dengan bebas melakukan tindakantindakan hukum yang bersangkutan dengan kegiatan ekonomi dan bisnis, tanpa perlu mendapat ijin dan bantuan suaminya. 
Kemudian dalam Pasal 31 ayat (3) disebutkan "Suami adalah kepala keluarga dari isteri adalah ibu rumah tangga". Ketentuan ini sebetulnya hanya merupakan pembagian tugas antara suami dan isteri dalam membina rumahtangga. Mendudukkan suami sebagai kepala keluarga dan isteri sebagai ibu rumah tangga secara hukum adalah cukup alasan, sebab bagaimanapun keinginan seorang isteri untuk betul-betul menyamai kedudukan suami baik ditinjau dari segi fungsinya dalam rumah tangga maupun dari segi fungsi biologisnya masing-masing tentu ada perbedaannya. Suami mempunyai kedudukan sebagai kepala keluarga adalah cukup beralasan, sebab ditinjau dari segi kewajibannya suami sebagi seorang pria lebih rasionil dibanding dengan isteri, (Soemiyati, 2007: 93).

\subsection{Ketentuan Hukum dalam Pembagian Harta Gonogini pasca perceraian}

Didalam suatu perkawinan dikenal yang namanya harta gono gini. Istilah harta gono gini sering menjadi hangat diperbincangkan dan banyak menyita perhatian publik, terlebih lagi yang menyangkut kasus perceraian terkait perselisihan tentang pembagian harta gono gini yang dipublikasikan kepada umum. Perkara perceraian yang menjadi pokok perkara justru akan semkain rumit dan berbelit-belit bahkan sering mengundang emosional dalam sidang-sidang perceraian di pengadilan bila dikomulasi dengan tuntutan pembagian harta gono gini, atau apabila ada rekonvensi harta gono gini dalama perkara perceraian.

Setiap terjadinya perceraian pasti akan membawa dampak dalam hal pembagian harta gono gini. Penulis disini menemukan munculnya sebuah permasalahan dimana salah satu pihak merasa lebih berhak atas harta yang dipersengkatakan. Misalnya suami dan istri yang telah bercerai dan memperebutkan sebuah rumah. Dahulu rumah tersebut dibeli secara kredit oleh mereka, namun dalam perjalanannya istri lebih banyak membayar cicilan kredit tersebut, sehingga istri merasa sebagian besar dari nilai rumah tersebut merupakan bagiannya. Terkadang muncul sebuah pertanyaan, apakah nanti harta tersebuat akan dibagi sama antara suami istri tersebut. Jika itu terjadi, maka istri akan merasa tidak adil, karena kenyataannya yang banyak andil dalam harta tersebut lebih besar dari suaminya. Atau sebaliknya, suami yang bekerja siang malam mencari nafkah, sementara sang istri hanya tinggal di rumah mengurus anak dan mengurus rumah tangga. Dari hasil usaha suami, mereka telah dapat membeli beberapa macam, seperti rumah, tanah, dan sebagainya, dalam permasalahan tersebut, jika terjadi perceraian di antara mereka apakah istri akan mendapatkan bagian yang sama dari harta yang diperoleh dari jerih payah sang suami itu?

Menurut Anshary ketentuan tentang harta gono gini jelas sudah diatur dalam hukum positif yang berlaku di Indonesia bahwa harta yang boleh dibagi secara bersama bagi pasangan suami istri yang bercerai hanya terbatas pada harta yang diperoleh selama ikatan perkawinan. Adapun harta bawaan tetap dibawah kekuasaaan masing-masing (Anshary, 2016: 114).

UU perkawinan yang termaktub dalam Pasal 37 mengatur sebagai berikut: "bila perkawinan putus karena perceraian, harta gono gini diatur menurut hukumnya masingmasing", yang dimaksud dari istilah "hukumnya masing-masing" haruslah terlebih dahulu melihat penjelasan pasal tersebut, dalam penjelasan pasal tersebut, "yang dimaksud dengan hukumnya masing-masing ialah hukum agama, hukum adat dan hukum-hukum lainnya".

Penyelesaian harta gono gini bagi suami istri dapat dilakukan dengan tiga alternatif hukum, yaitu berdasarkan hukum agama, hukum adat atau hukum lainnya. Bagi orang yang beragama Islam, begitu pula bagi masyarakat yang masih berpegang teguh secara ketat kepada adat, sepanjang ia beragama islam maka jika terjadi sengketa pembagian harta gono gini akan diselesaikan berdasarkan hukum Islam. Sedangkan bagi masyarakat adat yang 
bukan beragama Islam maka akan diselesaikan berdasarkan hukum adat mereka sepanjang hal itu tidak diatur dalam ajaran agama mereka.

M. Yahya Harahap menyatakan bahwa pada dasarnya semua harta yang diperoleh selama ikatan perkawinan menjadi yurisdiksi harta gono gini yang dikembangkan dalam proses peradilan. Berdasarkan pengembangan tersebut maka harta perkawinan yang termasuk yurisdiksi harta gono gini adalah sebagai berikut, (Manaf, 2006: 59):

a) Harta yang dibeli selama dalam ikatan perkawinan berlangsung. Setiap barang yang dibeli selama ikatan perkawinan menjadi yuridiksi harta gono gini.

b) Harta yang dibeli dan dibangun pasca perceraian yang dibiayai dari harta gono gini. Suatu barang termasuk yurisdiksi harta gono gini atau tidak ditentukan oleh asal-usul biaya pembelian atau pembangunan barang yang bersangkutan, meskipun barang itu dibeli atau dibangun pasca terjadinya perceraian.

c) Harta yang dapat dibuktikan diperoleh selama dalam ikatan perkawinan. Semua harta yang diperoleh selama dalam ikatan perkawinan dengan sendirinya menjadi Harta Gonogini.

d) Penghasilan harta gono gini dan harta bawaan. Penghasilan dari yang berasal dari harta gono gini menjadi yurisdiksi harta gono gini, demikian pula penghasilan dari harta pribadi suami istri juga masuk dalam yurisdiksi harta gono gini. Segala penghasilan pribadi suami dan istri. Sepanjang mengenai penghasilan pribadi suami istri tidak terjadi pemisahan, bahkan dengan sendirinya tejadi penggabungan sebagai harta gono gini. Penggabungan penghasilan pribadi suami istri ini terjadi demi hukum, sepanjang suami istri tidak menentukan lain dalam perjanjian kawin.

Pasal 36 ayat (1) UU perkawinan yang menetukan bahwa berkaitan dengan Harta Gonogini, suami atau istri dapat bertindak atas persetujuan belah pihak, hal ini mencerminkan suatukedudukan yang setara terhadap kekuasaaan atas harta gono gini dalam perkawinan. Kedudukan yang setara antara suami dan istri terhadap harta gono gini tersebut, maka lahirlah tanggung jawab dari suami dan istri tersebut manakala mereka secara bersama-sama atau salah satu dari mereka melakukan suatu perbuatan hukum (Judiasih, 2015: 25).

Kalau hanya melihat kepada ketentuan Pasal 37 UU perkawinan dan penjelasan pasal tersebut, penulis menganggap bahwa pembagian harta gono gini seoalah-olah tidak ada acuan bakunya, karena dalam UU perkawinan tidak mengatur hal tersebut secara detail. UU perkawinan tidak disebutkan jumlah porsinya bahwa jika terjadi perceraian harta gono gini akan dibagi sama rata antara bekas suami dan bekas istri atau dalam jumlah lainnya. Sehingga menurut pendapat beberapah ahli hukum pembagian harta gono gini akan dilakukan secara berimbang, yang dimaksud dengan berimbang disini belum tentu sama rata, namun lebih kepada sejauh mana masing-masing pihak memasukkan kontribusi jasa dan usahanya dalam menghasilkan harta gono gini tersebut. Sehingga menurut sebagian ahli hukum, dengan dicantumkannya kata "diatur menurut hukumnya msing-masing", menunjukkan bahwa keputusan mengenai pembagian harta gono gini tersebut akan diserahkan kepada kebijaksanaan hakim, dengan demikian akan lebih memenuhi rasa keadilan dari para pihak yang bersengketa .

Untuk memahami ketentuan Pasal 37 UU perkawinan dan penjelasan pasalnya tidak menjadi pelik manakala kita menoleh kepada peraturan lain yang mengaturnya. Bagi bangsa Indonesia yang beragama bukan muslim dan tidak tunduk kepada hukum adat dan sepanjang agamanya tidak mengatur lain, pembagian harta gono gini sebagai akibat 
perceraian dapat mengacu pula pada ketentuan Pasal $128 \mathrm{KUH}$ perdata yang berbunyi: "setelah bubarnya persatuan, maka harta benda kesatuan dibagi dua antara suami dan istri, atau antara para ahli waris mereka masing-masing, dengan tak mempedulikan soal dari pihak yang manakah barang itu diperolehnya".

Di dalam buku "Harta Benda Perkawinan" yang ditulis oleh Sonny Dewi Judiasih menambahkan bahwa, pengaturan harta benda perkawinan dalam KUH perdata mempunyai ketentuan hukum yang berlainan dengan UU perkawinan, dimana menurut ketentual pasal 119 dinyatakan bahwa mulai saat perkawinan dilangsungkan, demi hukum berlakulah persatua bulat antara kekayaan suami dan istri (Judiasih, 2015: 25). Hal ini terdapat banyak perbedaan pendapat atau penjelasan dalam pembagian harta gono gini.

Menurut Undang-undang Nomor 1 Tahun 1974 tentang perkawinan, harta benda perkawinan dalam UU perkawinan hanya diatur dalam tiga pasal saja, yaitu Pasal 35 sampai dengan pasal 37 UU perkawinan. Pasal 35 UU perkawinan mengatur hal-hal sebagai berikut:

a) Harta benda yang diperoleh selama dalam perkawinan menjadi harta gono gini.

b) Harta bawaan dari masing-masing suami dan istri dan harta benda yang diperoleh masing-masing sebagai hadiah atau warisan adalah dibawah penguasaan masingmasing sepanjang pihak tidak menentukan lain.

Hilman Hadikusuma juga menambahkan, jika dibandingkan dengan uraian tentang harta perkawinan dalam Undang-undang Nomor 1 tahun 1974, maka uraian dalam KUH perdata lebih banyak sampai 18 pasal. Di dalam UU No. 1 tahun 1974 tentang perkawinan hanya diuraikan dalam tiga pasal saja. Antara kedua perundangan itu terdapat perbedaan yang asasi (Hadikusuma, 2007: 114).

Menurut UU No 1 tahun 1974 bahwa, harta benda yang diperoleh selama perkawinan menjadi harta gono gini. Sedangkan harta bawaan dari suami istri masing-masing baik sebagai hadiah atau warisan berada di bawah penguasaan masing-masing sepanjang para pihak tidak menentukan lain. Mengenai harta gono gini suami atau istri dapat bertindak atas persetujuan kedua belah pihak. Sedangkan harta bawaan masing-masing suami dan istri mempunyai hak sepenuhnya untuk melakukan perbuatan hukum mengenai harta bendanya. Bila perkawinan putus karena perceraian, harta gono gini diatur menurut hukumnya masing-masing. Yang dimaksud "hukumnya" masing-masing ialah hukum agama, hukum adat dan hukum-hukum lainnya.

Undang-undang Nomor 1 tahun 1974 tentang perkawinan lebih mendekati hukum adat dan hukum lain dan menjauhi hukum perdata Eropa yang jauh berbeda dari hukum Indonesia. Hal mana tidak berarti bahwa hukum perkawinan nasional kita itu telah menerima hukum adat yang menyangkut harta perkawinan. Memang ia mungkin sesuai bagi keluarga/rumah tangga yang bersifat parental, tetapi tidak sesuai dengan keluarga/rumah tangga yang bersifat patrilineal maupun matrilineal. Oleh karenanya di dalam Undang-undang dipakai kaidah 'sepanjang para pihak tidak menentukan lain', atau kaidah diatur menurut hukumnya masing-masing (Hadikusuma, 2007: 114).

Harta benda perkawinan menurut UU perkawinan terbagi dalam dua golongan, yaitu harta asal atau harta bawaaan dan harta gono gini atau sering disebut dengan harta gonogini. Pasal ini secara tegas mengatur soal pembagian harta gono gini akibat perceraian, dan dari pasal tersebut dapat ditarik paling tidak empat garis hukum. Pertama, pembagian harta gono gini dapat terjadi pada kasus cerai hidup dan cerai mati. Kedua, besaran perolehan dari harta gono gini itu masing-masing suami istri mendapat seperdua bagian sama. Ketiga, bagi kasus cerai mati, maka yang akan memperoleh bagian harta gono gini itu adalah para ahli 
warisnya. Keempat, untuk menentukan harta gono gini tidak memperhitungkan yang lebih dominan dalam berusaha. Artinya, selama harta benda itu diperoleh selama ikatan perkawinan, maka dihitung sebagai harta gono gini tanpa menghiraukan siapa yang lebih dominan dan lebih besar kontribusinya.

Pembagian harta gono gini pada kasus cerai hidup maupun kasus cerai mati, menurut ketentuan yang diatur dalam Pasal 128 KUH perdata maupun dalam UU perkawinan Nomor 1 Tahun 1974 tentang perkawinan dan kompilasi hukum Islam masing-masing pasangan suami istri mendapat seperdua bagian yang sama. Sebagaimana diketahui bahwa perceraian mempunyai akibat hukum tidak hanya diri pribadi mereka yang terkait perceraian, tetapi lebih dari itu mempunyai akibat hukum pula terhadap harta kekayaan suami istri yang diperoleh selama perkawinan dalam perselisian harta gono gini. Harta gono gini inilah yang akan menjadi ajang persengketaan antara suami istri, dan lembaga peradilan pun akan cukup berperan dalam proses penyelesaiannya tentang bagaimana harta gono gini akibat putusnya perkawinan, dan bagaimana pertimbangan hakim dalam menentukan pembagian harta gono gini akibat perceraian tersebut, dan ditinjau dari aspek lainnya.

Hasil penelitian yang dilakukan oleh Siti Urwatul Usqak bahwa proses penyelesaian dan pertimbangan hakim dalam menentukan pembagian harta gono gini yaitu : Hakim dalam proses pembagian harta bersama yaitu membagi harta bersama tersebut sama-sama $1 / 2$ (seperdua) penggugat dan tergugat sedangkan hakim dalam mempertimbangkan pembagian harta gono gini atau harta bersama tidak mesti terpaku terhadap UU tetapi sebagai hakim proses pertimbangan pembagian harta gono gini harus berdasarkan rasa keadilan karna hakim sendiri mempunyai asas kontralegen (Usqak, 2020: xiv).

Menurut Anshary dalam Pasal 37 UU perkawinan tidak mengatur secara tegas tentang bagaimana aturan yang sebenarnya soal pembagian harta gono gini, pasal tersebut hanya menyebut bahwa pembagian harta gono gini diatur menurut hukumnya masing-masing dijelaskan dalam penjelasan pasal dan menurut penjelasan pasal terdapat beberapa alternatif yang dapat ditempuh untuk menyelesaikan pembagian harta gono gini, yakni melalui hukum agama, atau hukum adat, atau hukum lainnya.

Dengan demikian, bagi orang-orang yang beragama Islam dengan sendirinya untuk menyelesaikan pembagian harta gono gini tentunya akan menggunakan aturan-aturan hukum agamanya yaitu ketentuan Hukum Islam. Di Indonesia, dalam bidang harta gono gini, umat islam di Indonesia telah berhasil merumuskan hukum-hukm normatif yang terdapat dalam Al-Qur'an, Al-Hadist, dan doktrin-doktrin Ulama Fikih yang termuat dalam kitab-kitab fikih menjadi hukum nasional dan merupakan hukum materiil bagi badan Pengadilan Agama dalam melaksanakan tugas-tugas yudisialnya menyelesaikan sengketa harta gono gini antara umat Islam. Aturan-aturan dimaksud dikemas dalam bentuk Intruksi Presiden berupa Kompilasi Hukum Islam, dalam Pasal 96 ayat (1) kompilasi hukum Islam diatur sebagai berikut: "Apabila terjadi cerai mati, maka separuh harta gono gini menjadi hak pasangan yang hidup lebih lama". Sedangkan dalam Pasal 97 kompilasi hukum Islam disebutkan: "Janda atau duda cerai hidup masing-masing berhak seperdua dari Harta Gonogini sepanjang tidak ditentukan lain dalam perjanjian perkawinan".

Pembagian harta gono gini, dapat di artikan bahwa, Pasal 96 kompilasi hukum islam mengatur pembagian harta gono gini antara seseorang yang meninggal dunia dengan pasangannya yang hidup lebih lama, yakni masing-masing mendapat seperdua bagian. Adapun Pasal 97 kompilasi hukum Islam mengatur pembagian harta gono gini antar suami istri yang cerai hidup, masing-masing mereka mendapat seperdua bagian pula, dengan demikian dapat diambil garis hukum bahwa menurut ketentuan kompilasi hukum Islam, 
baik terhadap kasus cerai mati maupun cerai hidup, masing-masing pasangan mendapat bagian seperdua dari harta gono gini.

Bagi bangsa Indonesia yang bukan beragama Islam, kecuali mereka yang tunduk kepada hukum adatnya dan sepanjang hukum agamanya tidak menentukan lain, maka pembagian harta gono gini diantara mereka mengacu kepada ketentuan Pasal $128 \mathrm{KHU}$ perdata yang berbunyi: "Setelah bubarnya persatuan, maka harta benda kesatuan dibagi dua antara suami dan istri, atau antara para ahli waris mereka masing-masing, dengan tak memperdulikan soal dari pihak yang manakah barang-barang itu diperolehnya".

Dari beberapa muatan pasal diatas dapat pula ditarik garis hukum bahwa seorang istri tidak mempunyai kewajiban mencari nafkah untuk keluarga, karena tugas istri menurut ketentuan Pasal 34 ayat (2) UU perkawinan adalah mengatur urusan rumah tangga dengan sebaik-baiknya. Tetapi jika seorang istri berkontribusi melakukan aktivitas yang bernilai ekonomisyang tujuannya membantu suami mencari nafkah keluarga, itu merupakan amal baik sang istri, tetapi bukan merupakan kewajiban. Ketentuan Pasal 34 ayat (2) UU perkawinan istri bertugas mengatur urusan rumah tangga sedangkan suaminya berusaha mencari nafkah keluarga, tetapi jika terjadi perceraian, istri tetap mendapat bagian yang sama dengan bagian yang diterima suaminya, yakni masing-masing mendapat bagisan yang sama. Sebab yang dimaksusd dengan istilah bekerja mencakup juga tugas-tugas domestik mengatur urusan rumah tangga.

Musthafa Lutfi dan Mulyadi Lutfi di dalam bukunya yang berjudul "Nikah Sirri" menyampaikan; Seperti dikemukakan sebelumnya bahwa secara subtansi nikah siri telah ada sejak lama, bila yang dimaksudkan dengan nikah siri tersebut adalah pernikahan yang tidak dicatat dalam catatan badan berwenang. Adapun bila menyangkut merahasiakan pernikahan, juga bukan hal yang baru karena para ulama tempo dulu (klasik) telah membahasnya, terutama yang terkait kerahasiaan pernikahan tersebut dengan wasiat kepada para saksi untuk merahasiakan kesaksian mereka (Luthfi \& R, 2010: 50).

Menurut UU No. 1 Tahun 1974 tentang perkawinan menjelaskan bahwa; Harta benda yang diperoleh selama perkawinan menjadi harta gono gini. Sedangkan harta bawaan dari suami istri masing-masing baik sebagai hadiah atau warisan berada di bawah penguasaan masing-masing sepanjang para pihak tidak menentukan lain. Mengenai harta gono gini, suami atau istri dapat bertindak atas persetujuan kedua belah pihak. Sedangkan harta bawaan masing-masing suami dan istri mempunyai hak sepenuhnya untuk melakukan perbuatan hukum mengenai harta bendanya. Hilman Hadikusuma menyatakan bahwa; Bila perkawinan putus karena perceraian, harta gono gini diatur menurut hukumnya masingmasing, yang dimaksud dengan hukumnya masing-masing ialah hukum agama, hukum adat, dan hukum-hukum lainnya (Hadikusuma, 2007: 114).

Apabila merujuk pada Pasal 35 UU Nomor 1 Tahun 1974 tentang perkawinan maka harta perkawinan itu terdiri dari; (1) harta gono gini, (2) Harta Bawaan, (3) Harta Hadiah, (4) Harta Warisan. harta gono gini adalah harta yang didapat suami istri salama perkawinan (Harta Pencarian). harta gono gini ini jika perkawinan putus (cerai mati atau cerai hidup) diatur menurut hukumnya masing-masing (Hukum adat, hukum agama, hukum lainnya). Harta bawaan yaitu harta yang dibawa masing-masing suami istri ke dalam ikatan perkawinan, mungkin berupa harta hasil jerih payahnya sendiri, dan mungkin juga berupa harta hadiah atau harta warisan yang didapat masing-masing suami istri sebelum atau sesudah perkawinan. Harta bawaan, harta hadiah dan harta warisan ini tetap dikuasai masing-masing, jika tidak ditentukan lain. 
Istilah-istilah tersebut berasal dari hukum adat yang berlaku di Indonesia. Menurut hukum adat harta perkawinan itu terdiri dari "Harta bawaan" (Lampung, Sesan, Jawa, gawan, batak, ragi-ragi), "Harta Pencarian" (Minangkabau: harta suarang, Jawa: ganagini, Lampung: massow besesak), dapat ditambahkan pula dengan "Harta Pemberian" (hadiah, hibah dan lain-lain). Kedudukan harta perkawinan ini tergantung pada bentuk perkawinan yang terjadi, hukum adat setempat dan keadaan masyarakat adat bersangkutan,apakah masyarakat itu masih kuat mempertahankan garis keturunan patrilineal, matrilineal atau parental/bilateral, ataukah berpegang teguh pada hukum agama, atau sudah maju dan mengikuti perkembangan zaman.

Pada umumnya dalam masyarakat yang bersifat patrilineal, karena masih mempertahankan garis keturunan pria, maka bentuk perkawinan yang kebenyakan berlaku adalah bentuk perkawinan dengan pembayaran jujur (kecuali masyarakat Bali yang tidak memakai uang jujur dan harta bawaan dari kerabat), dimana setelah perkawinan istri masuk dalam kekerabatan suami dan pantang cerai. Pada golongan masyarakat patrilineal ini pada dasarnya tidak ada pemisahan harta gono gini dan harta bawaan (hadiah/warisan). Kesemua harta yang masuk dalam ikatan perkawinan menjadi harta gono gini atau harta persatuanyang dikuasai oleh suami sebagai kepala keluarga/rumah tangga. Semua perbuatan hukum yang menyangkut harta perkawinan harus diketahui dan disetujui oleh suami, istri tidak boleh bertindak sendiri atas harta bawaannya tanpa persetujuan suami. Malahan diantara harta gono gini atau harta bawaan yang bernilai adat segala sesuatunya bukan hanya suami yang menguasai tetapi juga termasuk kerabat bersangkutan.

Jika terjadi perceraian yang tidak lagi dapat diatasi dengan musyawarah kerabat dan istri kembali ke kerabat asalnya atau ke tempat lain, ia tidak berhak membawa kembali harta bawaannya, apalagi jika perecraian itu terjadi dikarenakan kesalahan istri (berzina). Jika pihak kerabat istri menuntut juga agar semua harta bawaan dikembalikan, maka kewajiban pihak kerabat istri mengembalikan uang jujur dan semua biaya yang telah dikeluarkan pihak suami dalam penyelenggarakan perkawinan mereka. Hal ini jarang sekali terjadi, oleh karena jika terjadi berakibat pecahnya hubungan baik bukan saja diantara suami dan istri itu sendiri tetapi juga pecahnya hubungan kekerabatan antara besan dan selalu menjadi pengungingan orang ramai.

Masyarakat yang mempertahankan garis keuturnan wanita (Matrilineal). Perkawinan yang banyak berlaku adalah dala bentuk perakawinan semenda (tanpa pembayaran uang jujur), dimana setelah terjadi perkawinan nsuami masuk dalam kekerabatan istri atau tunduk pada penguasaan pihak istri (Minangkabau menjadi urang sumando). Pada golongan matrilineaal antara harta pencarian (harta gono gini) dapat terpisah dari harta bawaan suami, termasuk juga harta hadiah dan atau warisan yang dibawa masing-masing ke dalam perkawinan, dengan demikian harta yang dikuasai bersama adalah harta gono gini (harta pencarian) sedangkan harta lainnya tetap dikuasai suami dan istri masing-masing. Jika terjadi perceraian, maka yang sering menjadi masalah perselisihan adalah mengenai harta pencarian/ harta gono gini, sedangkan harta lainnya seperti harta bawaan (Rejang, harta pembujangan yang dibawa pria/bujang dan harta perjantian yg dibawa wanita/gadis) termasuk yang berasal dari hadiah atau warisan, tidak menjadi masalah perselisihan, kecuali apabila harta bawaan itu terlibat bercampur ke dalam harta gono gini.

Dalam buku "Harta benda perkawinan" yang ditulis Sonny Dewi Judiasih. menyampaikan bahwa, dalam Pasal 1 Kompilasi Hukum Islam atau yang lebih kita kenal dengan istilah KHI menyebutkan bahwa harta kekayaan dalam perkawinan atau syirkah adalah harta yang diperoleh baik sendiri-sendiri atau bersama-sama suami-istri selama 
dalam ikatan perkawinan berlangsung, dan selanjutnya disebut harta gono gini tanpa mempersoalkan terdaftar atas nama siapapun, (Judiasih, 2015: 17).

Harta gono gini dalam perkawinan tidak menutup kemungkinan adanya harta masing-masing suami dan istri, terhadap harta masing-masing tersebut, $\mathrm{KHI}$ menyatakan bahwa tidak ada percampuran antara harta suami dan harta istri karena perkawinan. Harta istri tetap menjadi hak istri dan dikuasai sepenuhnya oleh istri. Demikian pula harta suami tetap menjadi hak suami dan dikuasai sepenuhnya oleh suami.

Didalam Undang-undang perkawinan dan kompilasi hukum Islam, tentu banyak hal yang mengulas tentang pembagian harta gono gini. Dikarenakan ini menjadi sebuah refrensi dalam membangun sebuah rumah tangga, tetapi adapula beberapa persoalan ketika terjadinya sebuah perceraian, ini terkadang menjadi sebuah problem dalam penyelesaian permasalahannya. KHI di dalam Pasal 87 ayat (1) menyatakan bahwa; harta bawaan dari masing-masing suami dan istri dan harta yang diperoleh masing-masing sebagai hadiah atau warisan adalah dibawah penguasaan masing-masing, sepanjang para pihak tidak menentukan lain dalam sepanjang perkawinan, dan ini sejalan juga dengan Pasal 87 ayat (2) menyatakan bahwa; suami dan istri mempunyai hak sepenuhnya untuk melakukan perbuatan hukum atas harta masing-masing berupa hibah, hadiah, sodaqoh atau lainnya.

Ketika terjadi perselisihan antara suami dan istri tentang keberadaan harta gono gini, maka penyelesaian perselisihan itu diajukan ke pengadilan agama. Adapun beberapa perselisihan yang sering menjadi polemik dalam peneyelesaiannya adalah harta yang berwujud dan harta yang tak berwujud. Ini terkadang menjadi berdebatan yang sangat panjang, sehingga kedua belah pihak antara keluarga suami dan keluarga istri memunculkan konflik yang sangat besar. Undang-undang perkawinan (UUP) dalam pasal 91 aayat (2) kompilasi hukum Islam KHI menentukan bahwa; harta benda yang berwujud dapat meliputi benda tidak bergerak, benda bergerak dan surat-surat berharga.

Berdasarkan pasal ini penulis mencoba menganalisis tentang status pembagian harta gono gini maka suami atau istri mempunyai kebebasan untuk melakukan tindakan hukum apapun terhadap harta bawaannya sepanjang tidak mengandung klausula yang melanggar ketentuan agama, hukum dan kesusilaan. Perbuatan hukum yang dimaksud pasal di atas adalah perbuatan hukum yang mempunyai klausula yang halal seperti menghibahkan, menghadiahkan, mensadakahkan harta milik pribadinya, sebagaimana bunyi Pasal 87 ayat (2) kompilasi hukum Islam tersebut. Sedangkan yang dimaksud oleh kalimat " atau lainnya" dalam Pasal 87 ayat (2) kompilasi hukum islam tersebut termasuk menjual, mengadaikan, mengagunkan ke bank dan menghasiatkan harta bawaan. Namun demikian, meskipun pasal tersebut memberi kebebesan dan hak sepenuhnya kepada suami atau istri untuk melakukan perbuatan hukum terhadap harta bawaannya masing-masing, tetapi hukum tidak membenarkan melakukan perbuatan hukum yang mempunyai klausula yang tidak halal, seperti misalnya menjual atau mengadaikan harta bawaan dengan tujuan sebagai modal untuk berjudi, menggunakannya secara berfoya-foya yang mengarah kepada tindakan mubadzir.

Maka seorang suami yang melakukan tindakan hukum seperti menjual atau mengibahakan harta bawaannya kepada orang lain tidak diperlukan persetujuan dari istrinya. Demikian juga halnya seorang istri tidak perlu minta persetujuan dari suaminya untuk menjual harta benda yang bersatatus sebagai harta bawaannya jika sebelumnya tidak diperjanjikan dalam suatu perjanjian kawin bahwa mereka mencampurkan harta bawaan mereka menjadi satu kesatuan bulat. 
Harta bawaan yang berasal dari harta warisan misalnya, seorang suami atau istri tidak perlu meminta persetujuan dari pasangannya untuk menjual tanah yang dia peroleh dari warisan orangtauanya selama suami dan istri itu tidak memperjanjikan bahwa persetujuan belah pihak diperlukan dalam hal melakukan tindakan hukum atau harta warisan yang diterima suami tersebut. Jadi pada dasarnya, harta bawaan yang diperoleh dari bagian warisan atau wasiat, baik diperoleh sebelum maupun sesudah perkawinan, masing-masing suami istri berhak untuk melakukan tindakan hukum apapun karena harta tersebut dibawa penguasaannya dan merupakan milik pribadinya. Sehingga si suami tidak perlu meminta persetujuan istri untuk menjual tanah tersebut, begitupun sebaliknya istri. Akan tetapi, jika telah diperjanjikan bahwa diperlukan persetujuan pasangan dalam hal melakukan tindakan hukum atas harta bawaan yang berasal dari harta warisan, maka si suami atau istri harus meminta persetujuan dari pasangannya.

Bagaimana halnya dengan harta benda yang diperoleh dari hasil pengembangan harta gono gini yang dikuasai oleh salah satu pihak dari suami atau istri setelah terjadinya perceraian? Katakanlah umpamanya setelah terjadi perceraian, harta gono gini belum dibagi, dan keseluruhan harta gono gini tersebut dikuasai oleh mantan suami, sementara sang istri tidak diberi kesempatan untuk menguasai harta gono gini. Diantara harta gono gini tersebut terdapat satu unit pabrik yang bernilai sangat produktif, sehingga dari hasil pabrik sejak terjadinya perceraian dapat memperoleh keuntungan sehingga mantan suami dapat membeli beberapa objek harta benda lainnya, misalnya beberapa unit rumah toko (ruko).

Kasus tersebut terdapat dua hal yang menjadi persoalan adalah: pertama, apakah harta benda yang diperoleh sebagai hasil pengembangan dari harta gono gini yang belum dibagi setelah terjadinya perceraian, yang dalam ilustrasi diatas merupakan beberapa unit ruko, merupakan harta gono gini atau bukan? Kedua, andaikata harta tersebut termasuk harta gono gini, lalu bagaimana pembagiannya, berapa perolehan masing-masing mantan suami istri tersebut. Sebab perlu ditegaskan, bahwa yang mengelola harta gono gini setelah terjadinya perceraian sehingga menghasilkan objek lainnya yakni beberapa unit ruko tersebut adalah mantan suami, sementara mantan istri tidak diberi kesempatan oleh suami untuk mengelola harta gono gini dimaksud.

Didalam Undang-undang perkawinan UUP dan kompilasi hukum Islam KHI hanya mengatur bahwa segala harta benda yang diperoleh selama perkawinan merupakan harta benda bersama, sebagaimana telah diatur dalam Pasal 35 ayat (1) UU Perkawinan juncto Pasal 1 Huruf $\mathrm{f}$ Kompilasi Hukum Islam. Adapun harta benda yang diperoleh sebagai hasil pengembangan harta gono gini yang belum dibagi setelah terjadinya perceraian, tidak diatur dalam hukum.

Apabila terjadi kasus yang diajukan ke pengadilan sebagaimana disebutkan diatas, oleh karena tidak ditemukan aturannya dalam UU Perkawinan dan kompilasi hukum islam, juga didalam KUHperdata, maka acuan penerapan kasusnya merujuk kepada yurisprudensi Mahkamah Agung, bahwa harta benda yang dibeli dan dibangun sesudah perceraian yang dibiayai dari harta gono gini, untuk menentukan sesuatu barang termasuk objek harta gono gini dapat ditentukan oleh asal-usul uang biaya pembelian atau pembangunan barang yang bersangkutan, meskipun barang tersebut dibeli atau dibangun sesudah terjadi perceraian. Praktek ini sesuai dengan putusan Mahkamah Agung tanggal 5 Mei 1970 No. 803K/Sip/1970 yakni, apa saja yang dibeli setelah pisah tempat tinggal atau telah cerai sekalipun, jika uang pembelinya berasal dari harta gono gini maka dalam barang tersebut melekat harta gono gini meskipun telah berubah wujudnya (Anshary, 2016: 136). 
Dari putusan mahkamah agung tersebut harus ditafsirkan sedemikian rupa, sehingga harus dimaknai bahwa semua hasil pengembangan dari harta gono gini yang belum dibagi yang diperoleh setelah terjadinya perceraian antara suami istri, terlepas dari siapa yang menguasai dan mengelolah harta gono gini tersebut, secara yuridis harus dipandang sebagai harta gono gini mantan suami istri tersebut.

Patokan hukum sebagaimana dijelaskan di atas tidak semudah yang dibayangkan jika dihadapkan kepadasuatu sengketa harta gono gini di pengadilan. Jika misalnya seorang mantan istri menggugat pembagian harta gono gini yang dikuasai mantan suaminya setelah suami sebagai pengembangan harta gono gini setelah terjadinya perceraian, apabila suami menyangkal kebenaran dalil gugatan istri, membuktikan bahwa harta-harta yang dikuasai mantan suami merupakan harta gono gini dan merupakan hasil pengembangan harta gono gini setelah terjadinya perceraian.

\section{Kesimpulan}

Berdasarkan paparan di atas, maka dapat disimpulkan bahwa harta gono gini diartikan sebagai harta kekayaan yang dihasilkan oleh suami istri selama mereka diikat oleh tali perkawinan, atau dengan perkataan lain disebutkan bahwa harta gono gini itu adalah harta yang di hasilkan dengan jalan syirkah antara suami istri sehingga terjadi percampuran harta yang satu dengan yang lain dan tidak dapat di bedakan lagi. Dasar hukumnya dalah al-Qur'an surat an-Nisa'ayat 32, dimana dikemukakan bahwa bagi semua laki-laki ada bagian dari apa yang mereka usahakan dan semua wanita ada bagian dari apa yang mereka usahakan pula. Pembagian harta gono gini pada kasus cerai hidup maupun kasus cerai mati, sesuai ketentuan hukum masing-masing pasangan suami istri mendapat seperdua bagian yang sama, maka dasar pembagian harta gono gini disesuaikan dengan harta yang diperoleh selama terjadi ikatan perkawinan baik secara siri maupun secara hukum Negara.

\section{Daftar Referensi}

Alexander, O. (2019). Efektivitas Pembagian Harta Gono - Gini Pasca Perceraian dalam Persfektif Yuridis Sosiologis. El-Ghiroh: Jurnal Studi Keislaman, 16(1), 113-129. https://doi.org/10.37092/el-ghiroh.v16i01.70

Anshary, M. (2016). Harta Bersama Perkawinan dan Permasalahannya. Mandar Maju.

Hadikusuma, H. (2007). Hukum Perkawinan Indonesia Menurut: Perundangan, Hukum Adat, Hukum Agama. Mandar Maju.

Judiasih, S. D. (2015). Harta Benda Perkawinan: Kajian Terhadap Kesetaraan Hak dan Kedudukan Suami Dan Isteri Atas Kepemilikan Harta Dalam Perkawinan (D. Sumayyah (ed.)). Refika Aditama.

Labetubun, M. A. H., \& Fataruba, S. (2020). Implikasi Hukum Putusan Pengadilan terhadap Pembatalan Perkawinan. Batulis Civil Law Review, 1(1), 54-59. https:// doi.org/10.47268/ballrev.v1i1.430

Latupono, B. (2018). Pencatatan Perkawinan Di Indonesia Dikaitkan Dengan Good Governance. SASI, 24(2), 150-160.

Latupono, B. (2020a). Akibat Hukum dalam Perkawinan yang Dilakukan oleh Suami Tanpa Ijin Istri Sahnya. Batulis Civil Law Review, 1(1), 60-67. https:// doi.org/10.47268/ballrev.v1i1.431 
Latupono, B. (2020b). Pertanggungjawaban Hukum Ayah Terhadap Anak Setelah Terjadinya Perceraian. SASI, 26(2), 242-250. https:/ / doi.org/10.47268/sasi.v26i2.281

Latupono, B., Angga, L. O., Labetubun, M. A. H., \& Fataruba, S. (2020). Buku Ajar Hukum Islam Edisi Revisi. Deepublish.

Luthfi, M. M., \& R, M. L. (2010). Nikah Siri: Membahas tuntas: Definisi, Asal-Usul, Hukum serta Pendapat Ulama Salaf dan Khalaf. Wacana Ilmiah Press.

Manaf, A. (2006). Aplikasi Asas Equalitas Hak dan Kewajiban Suami Isteri dalam Penjaminan Harta Bersama pada Putusan Mahkamah Agung. Mandar Maju.

Soekanto, S., \& Mamudji, S. (2015). Penelitian Hukum Normatif, Suatu Tinjauan Singkat. In Jakarta : Raja Grafindo Persada. Rajawali Pers.

Soemiyati. (2007). Hukum Perkawinan Islam Dan Undang-Undang Perkawinan (Undang-Undang Nomor 1 Tahun 1974 tentang Perkawinan). Liberty.

Thalib, S. (2004). Hukum Kekeluargaan Indonesia. UI Press.

Usqak, S. U. (2020). Tugas Dan Peran Pengadilan Agama dalam Menyelesaikan Kasus Harta Gono Gini Sebagai Upaya Penyelesaian Konflik Keluarga Pasca Bercerai Suami Istri (Studi Kasus di Pengadilan Agama Mataram) [Universitas Muhammadiyah Mataram]. http://repository.ummat.ac.id/1052/ 